\title{
A Case of Schwannoma of the Chorda Tympani with Facial Palsy
}

\author{
Risa Kato ${ }^{1)}$, Hisashi Sugimoto ${ }^{1)}$, Makoto Ito $^{2)}$ and Tomokazu Yoshizaki ${ }^{1)}$
}

\begin{abstract}
We report herein on a rare case of schwannoma of the chorda tympani with facial palsy. A 34-year-old woman was referred to our hospital because of right facial palsy which was resistant to steroid intervention and anti-viral drugs. In the physical examination, a white mass was observed in the posterior superior quadrant of the tympanic membrane and the facial palsy score was $0 / 40$. Computed tomography revealed a tumor in the right chorda tympani, extending from the branch of facial nerve to the malleus. Based on the physical, physiological and imaging tests, the patient was diagnosed as having a tumor of the right chorda tympani with facial palsy. For the purpose of resection and definitive diagnosis of the tumor, a surgical intervention was performed. Histologically the tumor was diagnosed as a schwannoma, and immunohistochemically the tumor cells were positive for S-100. After surgery, the patient's facial palsy completely resolved in six weeks. There has been no finding of recurrence two years after surgery.
\end{abstract}

Keywords : schwannoma, chorda tympani, facial palsy

\section{References}

1) Huoh $\mathrm{KC}$ and Cheung SW : Chorda tympani neuroma. Otol Neurotol 31: 1172-1173, 2010.

2) Chai $F$, Vanopulos $K$ and McManus $T$ : Chorda tympani schwannoma. Aust N Z J Surg 70: 827-828, 2000.

3) Browning ST, Phillipps JJ and Williams N : Schwannoma of the chorda tympani nerve. J Laryngol Otol 114: 81-82, 2000.

4) Magliulo G, D’Amico R, Varacalli S, et al. : Chorda tympani neuroma: diagnosis and management. Am J Otolaryngol 21:
65-68, 2000.

5）梅田裕生, 高木 明, 佐藤進一, 他：鼓室神経叢由来と考 えられた中耳神経鞘腫症例. 日耳鼻会報 105: 812-815, 2002.

6) 小玉隆男：下位脳神経. 頭頸部の CT $\cdot$ MRI (多田信平, 黒崎喜久 編). 90-91頁, メディカル・サイエンス・イ ンターナショナル, 東京, 2002 .

7) 増田聖子：側頭骨内多発性神経鞘腫の一例. Facial Nerv Res 29: 145-147, 2009.
1) Department of Otolaryngology-Head and Neck Surgery, Kanazawa University Graduate School of Medical Science

2) Department of Pediatric Otolaryngology, Jichi Children's Medical Center Tochigi, Jichi Medical University
Corresponding Author Address : Risa Kato

risanosuke7@yahoo.co.jp 

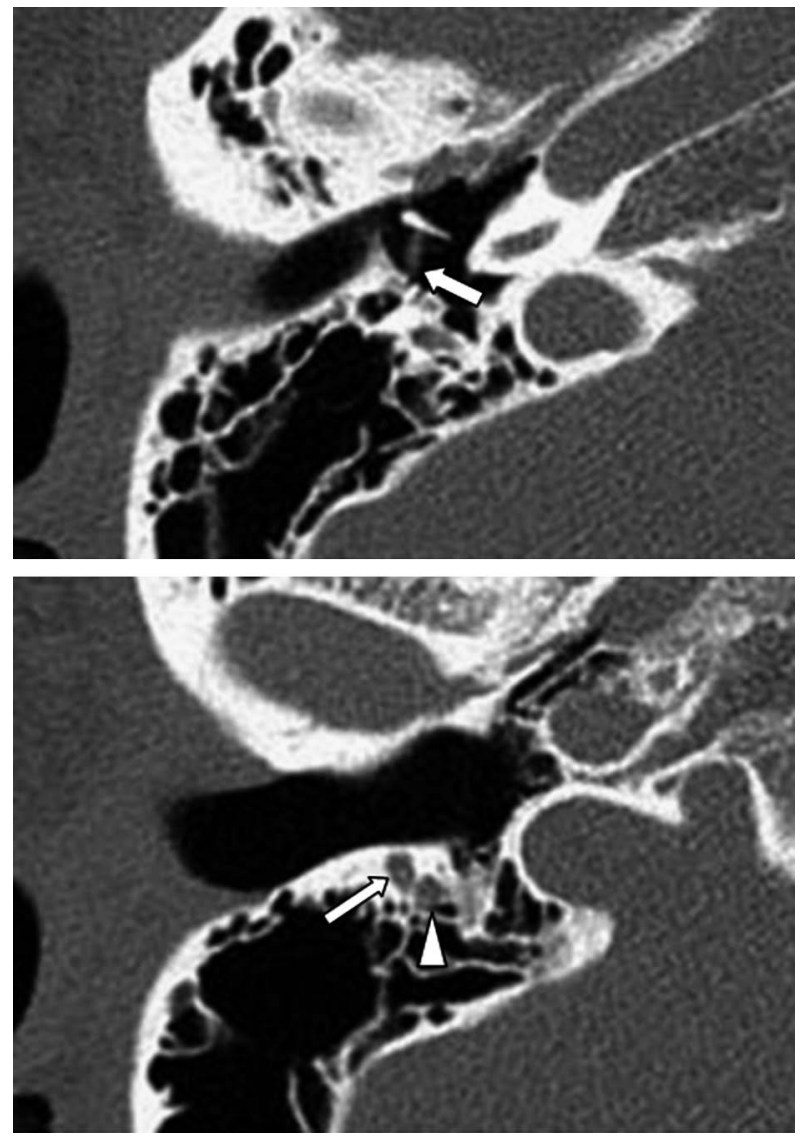

Temporal bone computed tomography

upper: The right chorda tympani is bulging as compared to that on the contralateral side.

lower (arrow, chorda tympani; arrowhead, facial nerve): The neural tube in the temporal bone is expanding.

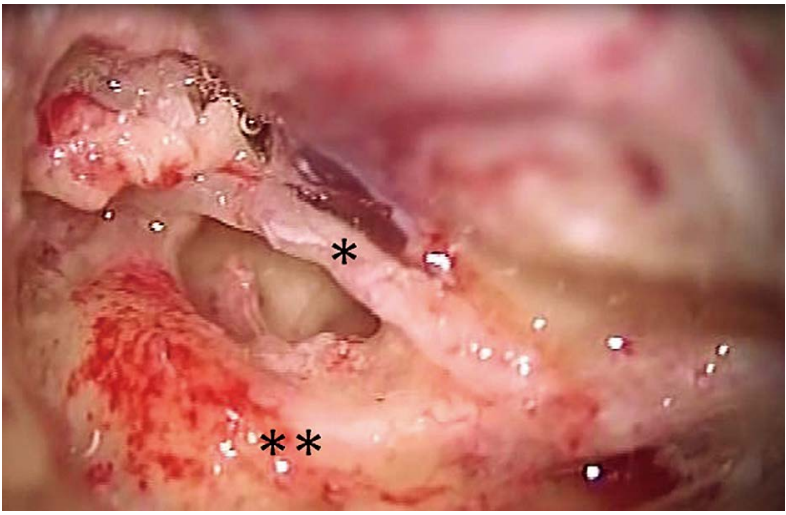

Surgical findings (* chorda tympani, ** facial nerve trunk)

The chorda tympani is edematous, and slightly reddish in color as compared with the trunk of the facial nerve. 